\title{
Chemical composition and antifungal activities of Ziziphora tenuir and Z. clinopodioides essential oils against dermatophytes
}

\author{
MOHADDESE MAHBOUBI, REZVAN HEIDARY TABAR*, ELAHEH MAHDIZADEH
}

Department of Microbiology

Medicinal Plants

Research Center of Barij

Kashan, Iran

*corresponding author: phone/fax: +988644465187, e-mail: rezvan_he@yahoo.com

\section{Summary}

Introduction: Ziziphora species are traditionally used for treatment of different infectious and non-infectious diseases as antiseptic agents.

Objective: The aim of this study was to evaluate the chemical composition of Ziziphora clinopodioides and $Z$. tenuir essential oils and their antifungal effects againt five strains of dermatophytes.

Methods: GC and GC-MS methods were used for essentional oils analize. The anti-elastase activities were determined by porcine pancreatic elastase assays.

Results: 48 different compounds were identified in these two essential oils, which thymol, $p$-cymene, 1,8 -cineole and $\gamma$-terpinene were their major components. The anti-dermatophyte activities of essential oils against dermatophytes showed that the essential oils (150 ppm) inhibited the mycelium growth, about 5-100\%, which $Z$. clinopodioides essential oil had higher mycelium growth inhibition (28-100\%) than that of $Z$. tenuir oil. The MIC and MFC values of essential oils were $0.01-1 \mu \mathrm{l} / \mathrm{ml}$. $0.5 \mu \mathrm{l} / \mathrm{ml}$ essential oils inhibited porcine pancreatic elastase, dose-dependently.

Conclusions: Due to the anti-dermatophyte and anti-elastase effects of Ziziphora sp., it can be considered as natural antifungal agent for more clinical and pre-clinical trials.

Key words: Anti-dermatophyte activity, Ziziphora sp., anti-elastase activity 


\section{INTRODUCTION}

Dermatophytosis as one superficial skin infections is caused by dermatophytes. Microsporum and Trichophyton are the most common dermatophytes, with high incidence in different parts of the world [1]. Produced proteolytic enzymes by dermatophytes as one virulence factor have crucial role in virulence of dermatophytes [2]. Treatment of fungal infections is more difficult than bacterial ones, because of fewer antifungal agents, high adverse effects, and appearance of drug-resistant strains [3]. Therefore, developing the new anti-dermatophyte agents with high efficacy, especially among medicinal plants [4], as natural sources of various metabolites or novel molecules, is essential [5].

Ziziphora genus (Lamiaceae family), with common name of "Kakuti" [6] has four species in Iran (Z. clinopodioides, Z. tenuir, Z. persica and Z. capitata) [7]. In Iran, Ziziphora sp. were used traditionally for treatment of some ailments such as common cold, heart ailments, gastrointestinal disorders, inflammation, depression, diarrhea and wound injuries [8, 9]. Generally, Ziziphora sp. essential oils and extracts potentially are known as antibacterial, anthelmintic [6], anti-dermatophyte [10], and antiviral agents [11]. The antibacterial activities of Ziziphora sp. essential oils were confirmed against Gram-positive and Gram-negative bacteria [12]. Although, the anti-dermatophyte effects of $Z$. clinopodioides essential oil towards dermatophytes obtained from patients with dermatophytosis [10] was the subject of one study, but there is no article comparing the antifungal activities of $Z$. tenuir and $Z$. clinopodioides essential oils against dermatophytes. Therefore, due to the effect of chemical compositions of essential oil on its antimicrobial activity, the chemical composition of $Z$. clinopodioides and $Z$. tenuir aerial parts essential oils and their antifungal effects were evaluated against four strains of dermatophytes. Furthermore, the potency of these essential oils was evaluated against elastase enzyme as one of virulence factor of dermatophytes.

\section{MATERIAL AND METHODS}

\section{Ziziphora sp. essential oil's extraction and che- mical composition analysis by GC and GC-MS}

Ziziphora clinopodioides and Ziziphora tenuir aerial parts at full flowering stages were collected from
Urmia suburb (Urmia Province, Iran) in June 2015.

The samples were identified and confirmed at Agriculture Department, Research Centre of Barij, Kashan, Iran. Each herbarium sample was deposited under the voucher numbers of 234-1 (Z. clinopodioides) and 192-1 (Z. tenuir).

The essential oils were extracted from aerial parts of plants by hydro-distillation method in Clevenger type apparatus. Essential oils were kept in sterile dark vials and stored at $4^{\circ} \mathrm{C}$ until used in the experiments.

The chemical compositions of essential oils were analyzed by GC-MS using a Thermofinnigan Trace GC/MS single quadruple mass spectrometer with AS 800 auto sampler. Capillary column, DB-5 (30 m $\times 0.25 \mathrm{~mm}$, film thickness $0.25 \mu \mathrm{m})$ were used. The column temperature was kept at $60^{\circ} \mathrm{C}$ for $5 \mathrm{~min}$ and then at $250^{\circ} \mathrm{C}$ for $10 \mathrm{~min}$. The injection volume was $0.2 \mu l$ with split ratio of $1 / 100$. Helium as carrier gas had the flow rate of $1.1 \mathrm{ml} / \mathrm{min}$. MS was taken at $70 \mathrm{eV}$ electron ionization, trap current $150 \mu \mathrm{A}$, and source temperature $200^{\circ} \mathrm{C}$. Identification was done by comparison of their retention indices (RI), mass spectra fragmentation with those on the stored Wiley 7n.1 mass computer library, and NIST (National Institute of Standards and Technology) [13].

\section{Dermatophytes strains and their preparation}

Trichophyton mentagrophytes ATCC 5054, Trichophyton rubrum ATCC 5143, Microsporum canis ATCC 5069, Microsporum gypseum ATCC 5070, Trichophyton schoenleinii ATCC 5221, were used. Dermatophytes were cultured on Sabouraud dextrose agar (SDA) medium and incubated at $20-25^{\circ} \mathrm{C}$ for 5-7 days. Microbial suspensions were prepared by suspending dermatophytes in sterile normal saline solution with $0.05 \%$ Tween 80 , followed by adjusting its turbidity to $105-106 \mathrm{CFU} / \mathrm{ml}$ in RPMI 1640 (Sigma).

\section{Evaluation of antifungal activity}

The antifungal evaluations were performed by micro-broth dilution assay and mycelium inhibition techniques as described below:

\section{Micro-broth dilution assay}

Determination of minimal inhibitory concentration (MIC) and minimal fungicidal concentration 
(MFC) of essential oils were performed by micro broth dilution assay. The essential oils were dissolved in DMSO and serially diluted in RPMI 1640 (sigma) medium at final concentrations in the ranges of $64-0.15 \mathrm{mg} / \mathrm{ml}$. Then, $100 \mu \mathrm{l}$ of each concentration of solutions and $100 \mu \mathrm{l}$ of diluted fungal suspensions (103-104 CFU/ml) were added to the wells of 96-microtiter plates. The plates were incubated at $20-25^{\circ} \mathrm{C}$ for $5-7$ days. The MICs were reported as the lowest concentration of oils that show no visible microbial turbidity in the wells. The first well that had no fungal growth on agar media was defined as MFC value (mg/ml) [14].

\section{Mycelium inhibition techniques}

Ziziphora sp. essential oils were mixed with SDA medium at final concentrations of $150 \mathrm{ppm}$. In control sets, sterilized water instead of essential oil was used. Then, $6 \mathrm{~mm}$ diameter of mycelial discs were cut out from cultures and inoculated on the surface of each prepared agar mediums. Inoculated plates were incubated as above and the observations were recorded on the seventh day [15].

According to $(\mathrm{dc}-\mathrm{dt}) / \mathrm{dc} \times 100$ formula, the percentage of inhibitory effects of Ziziphora essential oils against mycelium growth of dermatophytes were calculated (where $\mathrm{dc}=$ fungal colony diameter in control sets, $\mathrm{dt}=$ fungal colony diameter in treatment sets).

\section{Elastase inhibition effects of essential oils}

The activity of Ziziphora essential oils on porcine pancreatic elastase inhibition (Type IV, Sigma) were measured using Suc-Ala-Ala-Ala-pNA as the substrate by spectrophotometrical method. The reaction mixture contained different concentrations of essential oils $(1-0.125 \mu \mathrm{l} / \mathrm{ml})$ dissolved in $0.2 \mathrm{M}$ Tris- $\mathrm{HCl}$ buffer ( $\mathrm{pH} 8.0$ ) and $0.2 \mathrm{U}$ porcine pancreatic elastase. The reaction was started by adding the $0.8 \mathrm{mM}$ substrate and production of $\mathrm{p}$-nitroaniline was monitored at $405 \mathrm{~nm}$ using a 96-well reader for $20 \mathrm{~min}$ at $37^{\circ} \mathrm{C}$ [16].The inhibition percent of elastase was calculated according to formula:

$$
(1-\mathrm{B} / \mathrm{A})^{\star} 100
$$

where A is enzyme activity without essential oil and $\mathrm{B}$ is activity in presence of oils.

The experiment was performed in triplicate.

Ethical approval: The conducted research is not related to either human or animal use.

\section{RESULTS AND DISCUSSION}

\section{Chemical composition of Ziziphora sp. essential oils}

Ziziphora sp. essential oils were analyzed by GCMS and resulted in identification of 48 different compounds, representing $99.7 \%$ and $100 \%$ of total Z. tenuir and Z. clinopodioides essential oils content, respectively. Thymol (54.4\%), (E)-caryophyllene (6.8\%), carvacrol methyl ether (5.3\%), $\gamma$-terpinene $(5.1 \%)$ and $p$-cymene $(4.6 \%)$ were the main components of $Z$. clinopodioides essential oil. $\alpha$-terpineol (19.5\%), thymol (13.9\%), $p$-cymene

Table 1.

The chemical composition of Ziziphora clinopodioides and Z. tenuir essential oils

\begin{tabular}{llcc}
\hline Compound & RI & Z. clinopodioides [\%] & Z. tenuir [\%] \\
\hline$\alpha$-Thujene & 926 & 1.8 & - \\
\hline$\alpha$-Pinene & 933 & 1.2 & 3.2 \\
\hline Camphene & 948 & 0.6 & 1.64 \\
\hline Sabinene & 974 & - & 0.5 \\
\hline$\beta$-Pinene & 977 & 0.5 & - \\
\hline$\beta$-Myrcene & 989 & 1.9 & 2.5 \\
\hline$\alpha$-Phellandrene & 1005 & 0.5 & 0.7 \\
\hline$\alpha$-Terpinene & 1016 & 1.9 & 0.3 \\
\hline$p$-Cymene & 1024 & 4.6 & 8.8 \\
\hline Limonene & 1028 & 0.6 & 0.7 \\
\hline 1,8 -Cineole & 1031 & 3.5 & 4.2 \\
\hline$\beta$-Trans-ocimene & 1045 & 0.1 & 3.0 \\
\hline$\gamma$-Terpinene & 1058 & 5.1 & 2.5 \\
\hline Sabinene hydrate & 1066 & 0.3 & - \\
\hline Isoterpinolene & 1086 & - & 0.2 \\
\hline
\end{tabular}




\begin{tabular}{|c|c|c|c|}
\hline Terpinolene & 1088 & 0.2 & 0.2 \\
\hline Linalool & 1099 & 1.3 & 3.8 \\
\hline Nonanal & 1102 & 0.3 & - \\
\hline Camphor & 1143 & - & 1.5 \\
\hline$\beta$-Terpineol & 1159 & - & 2.7 \\
\hline Borneol & 1170 & 2.2 & 2.2 \\
\hline Terpinen-4-ol & 1182 & 0.98 & 2.3 \\
\hline$\alpha$-Terpineol & 1197 & 0.1 & 19.5 \\
\hline$\alpha$-Terpineol & 1206 & 0.3 & - \\
\hline trans-Dihydrocarvone & 1214 & 0.1 & - \\
\hline cis-Geraniol & 1222 & 0.1 & 5.83 \\
\hline Thymol methyl ether & 1237 & 0.1 & 1.0 \\
\hline Carvacrol methyl ether & 1247 & 5.3 & - \\
\hline Thymol & 1308 & 54.4 & 13.9 \\
\hline Carvacrol & 1312 & 2.6 & 2.6 \\
\hline Geranial & 1320 & - & 0.8 \\
\hline Germacrene & 1363 & - & 0.8 \\
\hline Geranyl acetate & 1383 & - & 5.2 \\
\hline (E)-caryophyllene & 1423 & 6.8 & 3.4 \\
\hline Aromandendrene & 1441 & 0.1 & 0.1 \\
\hline$\alpha$-Humulene & 1455 & 0.2 & 0.1 \\
\hline Geranyl propionate & 1475 & - & 0.2 \\
\hline Bicyclogermacrene & 1494 & - & 0.5 \\
\hline Viridflorene & 1496 & 0.3 & - \\
\hline$\alpha$-Muurolene & 1499 & - & 0.2 \\
\hline epi-Bicyclosesquiphellandrene & 1506 & - & 0.6 \\
\hline epi-Muurolene & 1513 & - & 0.4 \\
\hline Geranyl isobutyrate & 1514 & - & 0.2 \\
\hline$\delta$-Cadinene & 1530 & - & 0.3 \\
\hline (E)- $\alpha$-Bisabolene & 1543 & 1.5 & 0.3 \\
\hline Spathulenol & 1580 & 0.2 & 1.2 \\
\hline Caryophyllene oxide & 1585 & 0.2 & 0.2 \\
\hline Farnesol & 1689 & - & 1.5 \\
\hline
\end{tabular}

RI - retention index, (-) not found

$(8.8 \%)$, cis-geraniol $(5.8 \%)$, and geranyl acetate (5.2\%) were the main constituents of $Z$. tenuir essential oil (tab. 1).

The chemical compositions of Ziziphora sp. essential oils were the subject of several studies. In contrast to our results, many of them exhibited that Ziziphora sp. (Z. clinopodioides subsp. rigida and $Z$. taurica subsp. cleonioides and $Z$. tenuior) essential oils were rich in pulegone [17-19]. Ozturk et $a l$., indicated that main constituents of $Z$. clinopodioides aerial parts essential oils were pulegone (31.9\%), 1,8-cineole (12.2\%), limonene (10.5\%), menthol (9.1\%), $\beta$-pinene (6.9\%) and menthone (6.7\%) [20]. The main constituents of $Z$. clinopodioides ssp. rigida essential oils from nine populations of the Lashgardar region (Hamedan Province, Iran) were pulegone [7]. In another study, Z. tenuir aerial part essential oil from alpine regions (Kerman province of Iran) contained pulegone
(71.2-85.3\%), limonene (0.51-7.8\%), thymol (1.0$4.3 \%)$, and menthone (0.01-3.7\%) [19]. According to our results, the major constituent of $Z$. clinopodioides and $Z$. tenuir essential oils were thymol and $\alpha$-terpineol, respectively. These data do not correspond with above mentioned reports [7, 17-20].

However, carvacrol (64.2\%), thymol (19.2\%), p-cymene $(4.8 \%)$ and $\gamma$-terpinene $(4.6 \%)$ were the major components of the $Z$. clinopodioides essential oil from Kermanshah province (in the west of Iran) [6]. Aghajani et al. evaluated two samples of $Z$. clinopodioides essential oils from the Lorestan province of Iran and stated that in one sample thymol (53.6\%), $p$-cymene (10.5\%), carvacrol (8.7\%) and $\gamma$-terpinene $(6.7 \%)$ were the major constituents, while in other sample 1,8-cineole (21.6\%) and terpinen-4-ol (18.2\%) were the major components [21]. Therefore, pulegone was not the main component of essential oils in that literature. These 
findings are in agreement with results of our study. The chemical composition of $Z$. tenuir essential oil was not the subject of other studies.

Therefore, we can conclude that pulegone, 1,8-cineole, thymol, carvacrol, $p$-cymene and limonene can considered as the major compounds of Ziziphora sp. [6, 7]. Difference in the essential oils compositions might be arisen from several factors such as collection time, environmental and climatic conditions, and geographical region or plant materials $[6,8]$.

\section{Anti-dermatophyte activity of Ziziphora sp.}

The mycelium inhibitory effects of Ziziphora oils showed that all tested fungi were inhibited significantly by essential oils. According to table 2, $150 \mathrm{ppm}$ of essential oils showed $5.2-100 \%$ of dermatophytes mycelium growth inhibition, while $Z$. clinopodioides essential oil with inhibition percent of 28-100, showed the best inhibitory effect against mycelium growth than that of $Z$. tenuir essential oil (5-23\%) (tab. 2). T. schoenleinii and T. rubrum showed more sensitivity to Ziziphora sp. essential oils.

Table 3 summarizes the anti-dermatophyte effects of Ziziphora sp. by micro-broth dilution assay and indicates that the MIC and MFC values the ranged of $0.06-1$ and $0.125-1 \mu \mathrm{l} / \mathrm{ml}$ for $Z$. tenuir essential oil and $0.01-0.06$ and $0.01-0.06 \mu l / \mathrm{ml}$ for $Z$. clinopodioides essential oil, respectively, while $Z$. clinopodioides essential oil had better anti-dermatophyte effect than $Z$. tenuir essential oil. M. gypseum and T. schoenleinii were the most sensitive microorganisms tested by $Z$. clinopodioides essential oils. The MIC and MFC values for Z clinopodioides essential oil against $M$. gypseum and T. schoenleinii were 0.01 and $0.01 \mu l / \mathrm{ml}$, followed by M. canis, T. mentagrophytes. T. rubrum was the less sensitive dermatophyte to Z . clinopodioides essential oil (Table 3). Z. tenuir essential oil showed the best activity against T. mentagrophytes (MIC, MFC $=0.06$ and $0.125 \mu \mathrm{l} / \mathrm{ml}$ ), followed by M. canis, M. gypseum, T. rubrum and T. schoenleinii.

Anti-fungal activity of Ziziphora essential oils were investigated in limited articles $[10,16]$.

Table 2.

Inhibition percent of Ziziphora essential oils by mycelium inhibition technique

\begin{tabular}{llllll}
\hline & \multicolumn{5}{c}{ Species } \\
\cline { 2 - 5 } Essential oil & M. canis & T. rubrum & M. gypseum & T. schoenleinii & T. mentagrophytes \\
\hline Z. clinopodioides & $59.1 \%$ & $60.9 \%$ & $48.8 \%$ & $100 \%$ & $28.2 \%$ \\
\hline Z. tenuir & $5.7 \%$ & $15.2 \%$ & $5.2 \%$ & $23.6 \%$ & $14.3 \%$
\end{tabular}

Table 3.

Anti-dermatophyte activity of Ziziphora essential oils by micro broth dilution assay

\begin{tabular}{|c|c|c|c|c|}
\hline \multirow{3}{*}{ Essential oil } & \multicolumn{4}{|c|}{ Dermatophyte } \\
\hline & \multicolumn{2}{|c|}{ Z. tenuir $[\mu \mathrm{l} / \mathrm{ml}]$} & \multicolumn{2}{|c|}{ Z. clinopodioides $[\mu \mathrm{l} / \mathrm{ml}]$} \\
\hline & MIC & MFC & MIC & MFC \\
\hline M. canis & 0.125 & 0.125 & 0.01 & 0.03 \\
\hline M. gypseum & 0.25 & 0.5 & 0.01 & 0.01 \\
\hline T. mentagrophytes & 0.06 & 0.125 & 0.03 & 0.03 \\
\hline T. rubrum & 0.25 & 0.5 & 0.06 & 0.06 \\
\hline T. schoenleinii & 1 & 1 & 0.01 & 0.01 \\
\hline
\end{tabular}


Khosravi et al. [10] evaluated anti-fungal properties of some essential oils including $Z$. clinopodioides by micro-broth dilution assay and have been stated that this essential oil had antifungal activity against $A$. fumigates and A. flavus with $\mathrm{MIC}_{90}$ ranging from 0.25 to $1.5 \mathrm{mg} / \mathrm{ml}$ and also against some dermatophytes (T. mentagrophytes, T. rubrum, E. floccosum, M. gypsum and M. canis) in the range of $1-2 \mathrm{mg} / \mathrm{ml}$ (MIC) and 2-4 mg/ml (MFC) [10]. In another research, the anti-dermatophytes evaluation of $Z$. clinopodioides essential oil with high content of pulegone (44.5\%) by mycelium inhibition technique showed that 120, $250 \mathrm{ppm}$ of essential oil inhibited the mycelium growth about $53.5 \%$ and $88.4 \%$ for Trichoderma reesei [16], while $150 \mathrm{ppm} Z$. clinopodioides essential oil from our study with high content of thymol (54.4\%) had the better anti-dermatophyte effects than the latter study.

Generally, obtained data showed that essential oils exhibited discrepancy levels of anti-dermatophyte activities. The principles of these differences in sensitivity may be related to difference in chemical composition of essential oils, intrinsic tolerance of microorganisms or measurement methods $[8,10]$. Therefore, it is important to perform future studies on the impact of each of these factors alone or in combination.

\section{Anti-elastase activity of Ziziphora sp. essential oils}

Elastase is the only enzyme that is capable of breaking down elastin, which determines the mechanical properties of connective tissue [22]. Furthermore, certain microorganisms produce extracellular enzymes with collagenolytic, elastinolytic or keratinolytic activities that are responsible for fungal pathogenicity on tissue invasion. It is seemed that these proteinases play multiple roles in pathogenesis on host, including degradation of the host structural barriers. The role of these proteolytic enzymes as virulence factors is identified in Sporothrix schenckii, dermatophytes, Aspergillus and candidiasis [23]. Several researches have been made in order to investigate compounds which inhibit elastase and can reduce the severity of diseases [16]. Natural compounds or plant extracts have been studied for their effects on inhibiting elastase activity, but no similar research have been done for impact of Ziziphora sp. essential oils on elastase enzymes. As it is shown figure $1,0.5 \mu \mathrm{l} / \mathrm{ml}$ of $Z$. clinopodioides and $Z$. tenuir essential oils can inhibit elastase enzyme dose dependently in same manner.

\section{CONCLUSIONS}

In this research, the anti-dermatophyte effects of $Z$. tenuir and $Z$. clinopodioides essential oils was evaluated against dermatophytes. Ziziphora sp. essential oils especially $Z$. clinopodioides essential oil with high content of thymol had better anti-dermatophyte effects against skin infections. Our findings also highlight the novel property of Ziziphora as anti-elastase agent for control of superficial dermatophytes. Although, the chemical composition of $Z$. clinopodio-

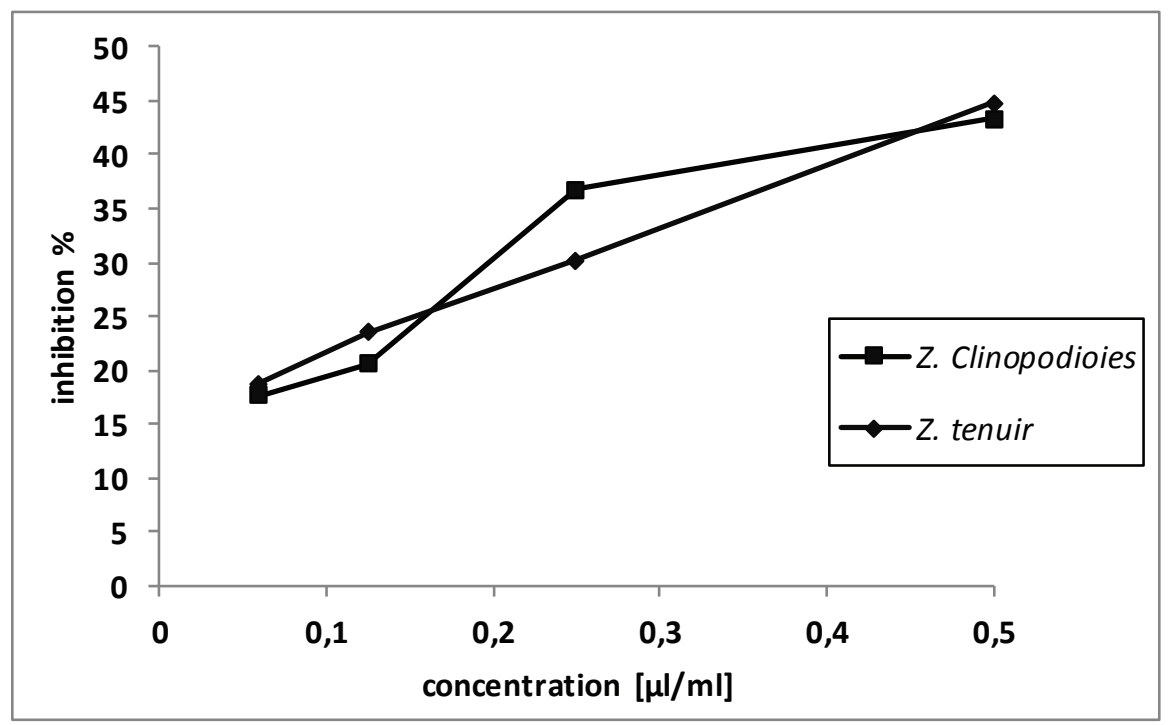

Figure 1.

Anti-elastase activity of Ziziphora sp. essential oils against elastase substrate 
ides essential oil, not $Z$. tenuir essential oil was the subject of some studies, but there was many discrepancies between the results. So, for the first time, we compared the chemical composition of $Z$. tenuir and $Z$. clinopodioides essential oils from Urmia, then, for the first time, the anti-dermatophyte and anti-elastase effects of these essential oils were compared.

\section{ACKNOWLEDGEMENTS}

This study is supported by Medicinal Plants, Research Center of Barij, Kashan, Iran.

Conflict of interest: Authors declare no conflict of interest.

\section{REFERENCES}

1. Behravan J, Ramezani M, Kasaian J, Sabeti Z. Antimycotic activity of the essential oil of Satureja mutica Fisch \& CA Mey from Iran. Flavour Fragr J 2004; 19(5):421-423. doi: http://dx.doi. org/10.1002/ffj.1328

2. Soares LA, Sardi JdCO, Gullo FP, Pitangui NdS, Scorzoni L, Leite FS, et al. Anti dermatophytic therapy: prospects for the discovery of new drugs from natural products. Braz J Microbiol 2013; 44:1035-1041. doi: http://dx.doi. org/10.1590/S1517-83822014005000011

3. Cruz M, Santos P, Barbosa A, De Mélo D, Alviano C, Antoniolli A, et al. Antifungal activity of Brazilian medicinal plants involved in popular treatment of mycoses. J Ethnopharmacol 2007;111(2): 409-412. doi: http://dx.doi.org/10.1016/j.jep.2006.12.005

4. Singh PS, Vidyasagar G. Antifungal screening of 61 folkloric medicinal plant extracts against dermatophytic fungi Trichophyton rubrum. J Appl Pharm Sci 2015; 5(05):38-44. doi: http://dx.doi. org/10.7324/JAPS.2015.50507

5. Fabricant DS, Farnsworth NR. The value of plants used in traditional medicine for drug discovery. Environ Health Perspect 2001; 109(Suppl 1):69. doi: http://dx.doi.org/10.2307/3434847

6. Shahbazi Y. Chemical composition and in vitro antibacterial effect of Ziziphora clinopodioides essential oil. Pharm Sci 2015; 21(2):51-56. doi: http://dx.doi.org/ 10.15171/PS.2015.17

7. Sonboli A, Atri M, Shafiei S. Intraspecific variability of the essential oil of Ziziphora clinopodioides ssp. rigida from Iran. Chem Biodivers 2010; 7(7):1784-1789. doi: http://dx.doi.org/10.1002/ cbdv.200900336

8. Ozturk S, Ercisli S. Antibacterial activity and chemical constitutions of Ziziphora clinopodioides. Food Control 2007; 18(5):535-540. doi: http:// dx.doi.org/10.1016/j.foodcont.2006.01.002

9. Khodaverdi-Samani H, Pirbalouti AG, Shirmardi H-A, Malekpoor F. Chemical composition of essential oils of Ziziphora clinopodioides Lam. (endemic Iranian herb) collected from different natural habitats. Indian J Tradit Know 2015; $1(1): 57-62$.

10. Khosravi RA, Shokri H, Farahnejat Z, Chalangari R, Katalin M. Antimycotic efficacy of Iranian medicinal plants towards dermatophytes obtained from patients with dermatophytosis. Chin J Nat Med 2013; 11(1):43-48. doi: http:// dx.doi.org/10.1016/S1875-5364(13)60006-0

11. Reichling J, Schnitzler P, Suschke U, Saller R. Essential oils of aromatic plants with antibacterial, antifungal, antiviral, and cytotoxic properties - an overview. Complement Med Res 2009; 16(2):79-90. doi: http://dx.doi. org/10.1159/000207196

12. Tumen G, Ayhan Z. Antimicrobial activity of essential oils of two Ziziphora species growing in Turkey. Fitoterapia 1992; 63:264-265.

13. Adams R. Identification of essential oil components by gas chromatography/mass spectroscopy. J Am Soc Mass Spectrom. 1997; 6(8):671-672. doi: http://dx.doi.org/10.1016/j. jasms.2005.07.008

14. Mahboubi M, HeidaryTabar R, Mahdizadeh E. The anti-dermatophyte activity of Zataria multiflora essential oils. J Mycol Med 2017; 27(2):232-237. doi: http://dx.doi.org/10.1016/j. mycmed.2017.03.001

15. Mahboubi M, Kazempour N. The antifungal activity of Artemisia sieberi essential oil from different localities of Iran against dermatophyte fun- 
gi. J Mycol Med 2015; 25(2):e65-e71. doi: http:// dx.doi.org/10.1016/j.mycmed.2015.02.042

16. Mori M, Ikeda N, Kato Y, Minamino M, Watabe $\mathrm{K}$. Inhibition of elastase activity by essential oils in vitro. J Cosmet Dermatol 2002; 1(4):183187. doi: http://dx.doi.org/10.1111/j.14732165.2002.00059.x

17. Salehi P, Sonboli A, Eftekhar F, Nejad-Ebrahimi S, Yousefzadi M. Essential oil composition, antibacterial and antioxidant activity of the oil and various extracts of Ziziphora clinopodioides subsp. rigida (BOISS.) RECH. f. from Iran. Biol Pharm Bull. 2005; 28(10):1892-1896. doi: http:// dx.doi.org/10.1248/bpb.28.1892

18. Meral GE, Konyalioglu S, Ozturk B. Essential oil composition and antioxidant activity of endemic Ziziphora taurica subsp. cleonioides. Fitoterapia. 2002; 73(7):716-718. doi: http://dx.doi. org/10.1016/S0367-326X(02)00244-7

19. Pirbalouti AG, Amirkhosravi A, Bordbar F, Hamedi B. Diversity in the chemical composition of essential oils of Ziziphora tenuior as a potential source of pulegone. Chemija 2013; 24(3):234-239.
20. Ozturk S, Ercisli S. The chemical composition of essential oil and in vitro antibacterial activities of essential oil and methanol extract of $\mathrm{Zi}$ ziphora persica Bunge. J Ethnopharmacol 2006; 106(3):372-376. doi: http://dx.doi.org/10.1016/j. jep.2006.01.014

21. Aghajani Z, Assadian F, Masoudi SH, Chalabian F, Esmaeili A, Tabatabaei-Anaraki M, Rustaiyan A. Chemical composition and in vitro antibacterial activities of the oil of Ziziphora clinopodioides and Z. capitata subsp. capitata from Iran. Chem Nat Compd 2008; 44(3):387-389. doi: http://dx.doi.org/10.1007/s10600-008-9073-4

22. Moon J-Y, Yim E-Y, Song G, Lee NH, Hyun C-G. Screening of elastase and tyrosinase inhibitory activity from Jeju Island plants. Eurasia J Biosci 2010; 4. doi: http://dx.doi.org/10.5053/ ejobios.2010.4.0.6

23. Voltan A, Donofrio F, Miranda E, Moraes R, Mendes-Giannini MJS. Induction and secretion of elastinolytic and proteolytic activity in cultures of Paracoccidioides brasiliensis. Rev Ciênc Farm. Básica Apl 2008:97-106.

\title{
Skład chemiczny i działanie przeciwgrzybicze olejków eterycznych z Ziziphora tenuir i Z. clinopodioides przeciw dermatofitom
}

\author{
MOHADDESE MAHBOUBI, REZVAN HEIDARYTABAR*, ELAHEH MAHDIZADEH
}

Department of Microbiology

Medicinal Plants

Research Center of Barij

Kashan, Iran

*autor, do którego należy kierować korespondencję: tel./faks: +988644465187, e-mail: rezvan_he@yahoo.com 


\section{Streszczenie}

Wstęp: Rośliny z rodzaju Ziziphora są tradycyjnie stosowane w leczeniu różnych chorób infekcyjnych i nieinfekcyjnych ze względu na swe działanie antyseptyczne.

Cel: Celem pracy było określenie składu chemicznego olejków eterycznych Ziziphora clinopodioides i $Z$. tenuir oraz działania przeciwgrzybiczego przeciwko pięciu dermatofitom.

Metody: Skład chemiczny olejków badano za pomocą GC i GC-MS. Działanie antyelastazowe badano z wykorzystaniem świńskiej trzustkowej elastazy.

Wyniki: W dwóch olejkach zidentyfikowano 48 różnych składników, wśród których głównymi były tymol, p-cymen, 1,8-cyneol i $\gamma$-terpinen. Badanie aktywności antydermatofitowej olejków pokazało, że olejki eteryczne (150 ppm) hamowały wzrost mycelium o około 5-100\%. Olejek eteryczny z Z. clinopodioides bardziej hamował wzrost mycelium (28-100\%) niż olejek z Z. tenuir. Wartości MIC i MFC olejków eterycznych wynosiły 0,01-1 $\mu \mathrm{l} / \mathrm{ml}$. Stężenie $0,5 \mu \mathrm{l} / \mathrm{ml}$ olejków eterycznych hamowało elastazę trzustki świńskiej w sposób uzależniony od dawki.

Wnioski: Z powodu działania antydermatofitowego i antyelastazowego Ziziphora może być uważana za naturalny środek przeciwgrzybiczy, który wymaga dalszych badań przedklinicznych i klinicznych.

Słowa kluczowe: dziatanie antydermatofitowe, Ziziphora, działanie antyelastazowe 